\title{
GAMBARAN TINGKAT PENGETAHUAN MASYARAKAT TENTANG KEGAWATDARURATAN DI KAWASAN PARIWISATA
}

\author{
I Made Suindrayasa', Meril Valentine Manangkot ${ }^{2}$ \\ 1.2Program Studi Sarjana Keperawatan dan Profesi Ners, \\ Fakultas Kedokteran, Universitas Udayana \\ Email : suindrayasa@unud.ac.id
}

\begin{abstract}
ABSTRAK
Kondisi kegawatdaruratan merupakan kondisi yang terjadi tanpa diduga, kapan saja, dimana saja dan memerlukan penanganan segera. Pengetahuan tentang kegawatdaruratan sehari-hari diperlukan dalam mendukung industri pariwisata. Dengan peningkatan pengetahuan tentang kegawatdaruratan akan memberikan rasa aman dan nyaman bagi wisatawan. Penelitian ini bertujuan untuk menggambarkan pengetahuan masyarakat tentang kegawatdaruratan di kawasan pariwisata. Penelitian ini merupakan deskriptif yang melibatkan 95 responden. Hasil penelitian ini menunjukan tingkat pengetahuan masyarakat tentang kegawatdaruratan di kawasan wisata memiliki kategori sedang sebanyak 56,84\%. Kesimpulan dari penelitian ini adalah tingkat pengetahuan masyarakat tentang kegawatdaruratan masih perlu ditingkatkan. Saran dari penelitian ini perlunya upaya peningkatan pengetahuan masyarakat tentang kegawatdaruratan untuk mendukung industri pariwisata.
\end{abstract}

Kata Kunci : pengetahuan, kegawatdaruratan, pariwisata

\begin{abstract}
Emergency conditions are conditions that occur unexpectedly, anytime, anywhere and require immediate treatment. Knowledge of day-to-day emergencies is needed to support the tourism industry. With increased knowledge about emergencies it will provide a sense of security and comfort for tourists. This study aims to describe people's knowledge about emergencies in the tourism area. This research is a descriptive study involving 95 respondents. The results of this study indicate that the level of public knowledge about emergencies in tourist areas is in the moderate category of $56.84 \%$. The conclusion of this study is the level of public knowledge about emergencies still needs to be improved. Suggestions from this research are the need for efforts to increase public knowledge about emergencies to support the tourism industry.
\end{abstract}

Keywords: knowledge, emergency, tourism

\section{PENDAHULUAN}

Industri pariwisata merupakan tulang punggung perkonomian di Bali. Bali dikenal sebagai daerah pariwisata yang didatangi para wisatawan domestik dan internasional. Objek wisata di Bali selalu ramai dengan kunjungan wisatawan. Pura Tanah Lot merupakan ikon pariwisata pulau Bali. Objek wisata Tanah-Lot selalu ramai dengan kunjungan wisatawan. Pengetahuan tentang kegawatdaruratan sehari-hari sangat diperlukan dalam mendukung industri pariwisata. Dengan peningkatan pengetahuan tentang kegawatdaruratan akan memberikan rasa aman dan nyaman bagi wisatawan. Kejadian gawat darurat seringkali terjadi tanpa diduga. Kejadian tersebut dapat terjadi kapan saja, dimana saja dan memerlukan penanganan.

Basic Life Support (Bantuan Hidup Dasar) mupakan merangkaian usaha awal untuk mengembalikan fungsi pernafasan dan atau sirkulasi pada seseorang yang mengalami henti nafas dan atau henti jantung (cardiac arrest). Jika pada suatu keadaan ditemukan 
korban dengan penilaian dini terdapat gangguan tersumbatnya jalan nafas, tidak ditemukan adanya nafas dan atau tidak ada nadi, maka penolong harus segera melakukan tindakan yang dinamakan dengan istilah bantuan hidup dasar. Bantuan hidup dasar terdiri dari beberapa cara sederhana yang dapat membantu mempertahankan hidup seseorang untuk sementara. Beberapa cara sederhana tersebut adalah bagaimana menguasai dan membebaskan jalan nafas, bagaimana memberikan bantuan penafasan dan bagaimana membantu mengalirkan darah ke tempat yang penting dalam tubuh korban.

Dari studi pendahuluan yang sudah dilakukan di kawasan pariwisata Bali belum mempunyai respon kesigapan dalam penanganan kegawatdaruratan. Dari hasil observasi masyarakat di kawasan tersebut belum mandapatkan pelatihan tentang penanganan kegawatdaruratan sehari-hari. Dari hasil wawancara dengan kepala desa pada kawasan pariwisata didapat bahwa ada kejadian kegawatdaruratan di kawasan tersebut seperti serangan jantung, kecelakaan, dan tenggelam tetapi masyarakat tidak mengetahui penanganan pertama yang dilakukan untuk melakukan pertolongan. Selama ini yang dilakukan oleh masyarakat hanya membawa korban ke pelayanan kesehatan terdekat.

Dengan peningkatan pengetahuan masyarakat pelaku wisata tentang kegawatdaruatan sehari-hari, diharapkan menjadi aspek penting pendukung bidang pariwisata. Diharapkan juga meningkatkan kesigapan masyarakat terhadap kegawatdaruratan dan peningkatan kunjungan wisatawan ke Bali.

\section{METODE PENELITIAN}

Penelitian ini merupakan penelitian kuantitatif deskriptif yaitu menggambarkan atau mendeskripsikan secara sistematis, faktual, dan akurat dari sebuah variabel. Penelitian ini bertujuan untuk menggambarkan variabel tingkat pengetahuan masyarakat terhadap kegawatdaruratan di kawasan pariwisata. (Polit \& Beck, 2006). Populasi merupakan area yang general dan terdiri dari obyek/subyek. Populasi memiliki kualitas dan karakteristik yang khusus dan ditentulan oleh peneliti untuk dianalisa dan sehingga dapat disimpulkan (Arikunto, 2006). Populasi Dalam penelitian ini yaitu kepala keluarga di kawasan periwisata Tanah Lot Banjar Batugaing, Desa Beraban, Kecamatan Kediri Kabupaten Tabanan Bali. Jumlah kepala keluarga Banjar Batugaing, Desa Beraban \pm 120 kepala keluarga.

Sampel adalah pengambilan sebagian kecil objek dari populasi yang dianggap mewakili seluruh karakteristik populasi yang nantinya dilakukan penelitian (Arikunto, 2006). Perhitungan Sampel pada penelitian ini menggunakan rumus Slovin. Dari hasil perhitungan, jumlah sampel dalam penelitian ini berjumlah 95 responden.

Kriteria inklusi adalah kriteria subyek penelitian dari suatu populasi target dan dapat dijangkau untuk diteliti (Sugiono, 2011). Dalam penelitian ini yang termasuk inklusi penelitian adalah : responden yang berada pada di kawasan Banjar Batugaing, Desa Beraban Tabanan, memiliki tingkat pendidikan SMA/S1/S2/S3, dan berusia $20-45$ tahun. Kriteria eksklusi adalah menghilangkan / mengeluarkan subyek/sampel yang tidak layak diteliti 
menjadi sampel (Sugiyono, 2011). Dalam hal ini yang termasuk dalam kriteria eksklusi adalah : responden yang menolak untuk mengikuti penelitian ini.

Penelitian ini menggunakan teknik sampling yaitu nonprobability sampling. Nonprobability sampling yaitu suatu pengambilan sampel dimana tidak memberikam peluang atau kesempatan yang sama untuk setiap responden yang ada di dalam populasi (Polit \& Beck, 2012). Jenis taknik nonprobability sampling yaitu purposive sampling adalah metode pemilihan sampel yang memilih semua pasien yang ditemui peneliti yang sesuai dengan kreteria inklusi dan kreteria eksklusi dalam kurun waktu tertentu atau sampai peneliti menemukan jumlah sample yang diinginkan (Polit \& Beck, 2012). Penelitian ini berlokasi di Banjar Batugaing, Desa Beraban, Kecamatan Kediri, Kabupaten Tabanan Bali.

Langkah-langkah dalam pengolahan data dalam penelitian ini meliputi editing, coding, entry, dan tabulasi. Penelitian ini melindungi subjek peneliti dari pelanggaran hak asasi manusia. Peneliti dalam melaksanakan penelitian ini mempertimbangkan prinsip etik untuk melindungi responden. Terdapat tiga prinsip etik dalam penelitian keperawatan yaitu beneficient, menghormati martabat manusia, dan keadilan.

\section{HASIL PENELITIAN}

Hasil penelitian menunjukkan bahwa analisis univariat yang dilakukan menunjukan tingkat pengetahuan masyarakat tentang kegawatdaruratan. Dari hasil analisis kuisioner yang telah diberikan, tingkat pengetahuan masyarakat terhadap kegawatdaruratan kurang baik sebanyak 27 responden (28,42\%), pengetahuan sedang sebanyak 54 responden $(56,84 \%)$, dan pengetahuan baik sebanyak 14 responden $(14,74 \%)$.

\section{PEMBAHASAN}

Pariwisata atau turisme adalah suatu perjalanan yang dilakukan untuk rekreasi atau liburan dan juga persiapan yang dilakukan untuk aktivitas ini (Susanti, 2015). Bali dikenal sebagai daerah pariwisata yang didatangi para wisatawan domestik dan internasional. Pura Tanah Lot merupakan ikon pariwisata pulau Bali. Objek wisata Tanah-Lot selalu ramai dengan kunjungan wisatawan. Pengetahuan tentang kegawatdaruratan sehari-hari sangat diperlukan dalam mendukung industri pariwisata. Dengan peningkatan pengetahuan tentang kegawatdaruratan akan memberikan rasa aman dan nyaman bagi wisatawan. Kejadian gawat darurat seringkali terjadi tanpa diduga. Keberhasilan pertolongan penderita yang mengalami kondisi gawat salah satu nya ditentukan oleh kualitas dari pelayanan gawat darurat saat pertama kali mendapat pertolongan saat kejadian. 
Tabel 1

Tingkat Pengetahuan Masyarakat Terhadap Kegawatdaruratan Di Kawasan Pariwisata Tingkat Pengetahuan

\begin{tabular}{ccc}
\hline Kurang baik & 27 & 28,42 \\
\hline Sedang & 54 & 56,84 \\
\hline Baik & 14 & 14,74 \\
\hline Total & 95 & 100
\end{tabular}

Untuk memberikan kualitas pertolongan yang baik, maka masyarakat harus memiliki kemampuan untuk menanggulangi keadaan gawat darurat dan salah satu keadaan gawat darurat yang sering terjadi di masyarakat. Basic Life Support (Bantuan Hidup Dasar) merupakan merangkaian usaha awal untuk mengembalikan fungsi pernafasan dan atau sirkulasi pada seseorang yang mengalami henti nafas dan atau henti jantung (Yunita, 2011). Bantuan hidup dasar terdiri dari beberapa cara sederhana yang dapat membantu mempertahankan hidup seseorang untuk sementara. Beberapa cara sederhana tersebut adalah bagaimana menguasai dan membebaskan jalan nafas, bagaimana memberikan bantuan penafasan dan bagaimana membantu mengalirkan darah ke tempat yang penting dalam tubuh korban, sehingga pasokan oksigen ke otak terjaga untuk mencegah matinya sel otak.

\section{KESIMPULAN}

Basic Life Support (Bantuan Hidup Dasar) mupakan merangkaian usaha awal untuk mengembalikan fungsi pernafasan dan atau sirkulasi pada seseorang yang mengalami henti nafas dan atau henti jantung. Pengetahuan tentang kegawatdaruratan sehari-hari sangat diperlukan dalam mendukung industri pariwisata. Dengan peningkatan pengetahuan tentang kegawatdaruratan akan memberikan rasa aman dan nyaman bagi wisatawan. Hasil uji statistik yaitu tingkat pengetahuan masyarakat terhadap kegawatdaruratan kurang baik sebanyak 27 responden $(28,42 \%)$, pengetahuan sedang sebanyak 54 responden $(56,84 \%)$, dan pengetahuan baik sebanyak 14 responden $(14,74 \%)$.

Untuk peneliti selanjutnya diharapkan mengembangkan intervensi dalam peningkatan pengetahuan masyarakat tentang kegawatdaruratan di kawasan industri pariwisata. Untuk warga masyarakat di kawasan industri pariwisata supaya dapat menyebarkan informasi tentang pertolongan kegawatdaruratan di setiap sektor pariwisata di Bali.

\section{UCAPAN TERIMA KASIH}

Dalam kesempatan ini peneliti mengucapkan terima kasih kepada semua responden yang ikut serta dalam penelitian ini. Peneliti juga berterima kasih kepada pihak LPPM (Lembaga Penelitian dan Pengabdian Kepada Masyarakat) Universitas Udayana atas bantuan yang diberikan kepada peneliti.

\section{DAFTAR PUSTAKA}

Arikunto, S. (2006). Prosedur Penelitian Suatu Pendekatan Praktik, Jakarta : Rineka Cipta

Black, J.M., \& Hawks, J.H. (2014). Keperawatan Medikal Bedah. Manajemen Klinis Untuk Hasil yang Diharapkan. Edisi 8. Buku 2. Singapore : Elsevier

Corwin, E. (2009). Buku Saku Patofisiologi. Penerbit Buku Kedokteran: EGC.

Dharma, K.K. (2011). Metodologi 
Penelitian Keperawatan : Pedoman Melaksanakan dan Menerapkan Hasil Penelitian. Jakarta. C.V. Trans Info Media

Ganong, W.F. (2008). Buku Ajar Fisiologi Kedokteran. Edisi 22. Jakarta: EGC.

Guyton, A.C. \& Hall, J.E. (2008). Buku Ajar Fisiologi Kedokteran. Edisi 9, Jakarta : EGC.

Kozier \& Erb, (2009). Buku Ajar Praktik Keperawatan Klinis. Edisi 5. Jakarta : EGC.

Nursalam. (2008). Konsep dan Penerapan Metodologi Penelitian Ilmu Keperawatan. Edisi kedua. Jakarta: Salemba Medika.

Perry \& Potter. (2006). Buku Ajar Fundamental Keperawatan. Edisi 4. Vol.2. Jakarta: EGC.

Polancik. (2009). Empirical Research Method Poster. Jakarta.

Polit, D.F. \& Beck, C.T. (2012). Nursing research : generating and assesing evidence for nursing practice. Philadelphia : Lippincott.

Prentice, E.W. (2002). Therapeutic Modalities For Sports Medicine And Athletic Training. fifth edition: North Carolina.

Riwidikdo. (2009), Statistik Kesehatan, Mitra Cendika Press, Yogyakarta.

Setiadi. (2007). Konsep dan Penulisan Riset Keperawatan. Yogyakarta : Graha Ilmu.

Sopiyudin, (2011). Statistik Untuk Kedokteran dan Kesehatan Edisi 5. Jakarta, Salemba Medika.

Sitzman, Katheleen L., Eichelberger,Lisa Wrigh. (2011). Understanding the work of nurse theorist: a creative beginning. Ed 2nd. Ontario:Jones and Bartlett Publisher
Sugiyono. (2011). Statistika untuk Penelitian. Bandung : Alfabe 